\title{
Populasi
}

\section{Optimalisasi Modal Sosial Keluarga Muda dalam Membangun Ketahanan Ekonomi di Era Covid-19: Studi Kasus di Perdesaan Jawa}

\author{
Setiadi \\ Jurusan Antropologi Fakultas IImu Budaya, Universitas Gadjah Mada \& Program Studi \\ Magister dan Doktor Kepemimpinan dan Inovasi Kebijakan, Sekolah Pascasarjana, \\ Universitas Gadjah Mada, Yogyakarta
}

Korespondensi: Setiadi (e-mail: setiadi_antro@ugm.ac.id)

\begin{abstract}
Abstrak
Pandemi Covid-19 telah menyebabkan berbagai dampak nonkesehatan akut bagi berbagai lapisan masyarakat, tidak terkecuali para keluarga muda di perdesaan Jawa. Artikel ini menyajikan hasil penelitian yang berfokus pada pengalaman keluarga muda yang bekerja pada sektor informal dalam mengatasi dampak ekonomi COVID-19. Dalam penelitian ini, keluarga muda adalah mereka yang menikah kurang dari 10 tahun dan/atau memiliki anak tertua berusia kurang dari 10 tahun. Dengan menggunakan pendekatan antropologi dan metode pengumpulan data melalui observasi partisipasi dan wawancara mendalam, penelitian ini menyimpulkan bahwa ada dua faktor yang menyebabkan mereka menjadi kelompok paling rentan, tetapi sekaligus mampu menghadapi situasi darurat secara ekonomi, yakni pertama, kemampuan mereka mengoptimalkan modal sosial, sehingga mampu meningkatkan kapasitas diri dan keluarga dalam menghadapi kerentanan ekonomi. Mereka melakukan berbagai kegiatan ekonomi produktif dengan mengoptimalkan jaringanjaringan kerja yang sangat terbatas untuk melangsungkan kehidupan. Kedua, sebagai kesatuan rumah tangga, secara internal mereka melakukan pengelolaan pendapatan yang minim secara cermat, sehingga mampu bertahan dan memenuhi kebutuhan minimum rumah tangga.
\end{abstract}

Kata kunci: dampak ekonomi; pendekatan antropologi; kerentanan ekonomi; modal sosial; keluarga muda 


\title{
Optimizing Social Capital in Young Families for Resilience Building During the Covid-19 Pandemic: A Case Study in Rural Areas of Java, Indonesia
}

\begin{abstract}
The Covid-19 pandemic has caused acute non-health impacts for various levels of society, including young families in rural areas of Java. This study presents the results of research that focus on the experiences of young families who work in the informal sector in overcoming the economic impacts due to the Covid-19 pandemic. The young families in this study were those who got married less than 10 years and/or had the oldest child aged less than 10 years. By using an anthropological approach and applying data collection method through participatory observations and in-depth interviews, this study concluded that there were two factors that made them be the most vulnerable group, yet they could face economic emergencies at the same time, such as first, their ability to optimize social capital to increase their own capacity and their family's capacity in the face of economic vulnerability. They did productive economic activities by optimizing very limited work networks to survive their life. Second, they carefully performed minimal income management so that they could survive and fulfill the minimum household needs as a household unit.
\end{abstract}

Keywords: economic impacts; anthropological approach; economic vulnerability; social capital; young families

\section{Pendahuluan}

Pandemi Covid-19 belum menunjukkan tanda-tanda akan berakhir dan telah memicu kekhawatiran terhadapkrisis ekonomi dan resesi di seluruh dunia. Selain itu, kebijakan jarak sosial, isolasi diri, dan pembatasan perjalanantelahmenyebabkan berkurangnya tenaga kerja di semua sektor ekonomi dan menyebabkan banyak pekerjaan hilang (Nicola et al., 2020). Indonesia juga turut terpukul cukup parah oleh Covid-19 (Setiati and Azwar, 2020) yang ditandai dengan dampak luar biasa secara ekononi, dengan total pekerja sektor formal dan informal yang terdampak Covid-19 per 1 Mei 2020 sebanyak 1.722.958 orang (Putri et al., 2020). Dalam menghadapi pandemi ini, pemerintah dan masyarakat melakukan beragam adaptasi dengan menyiapkan strategistrategi jangka pendek dan jangka panjang sambil terus berharap adanya vaksin virus Covid-19 (Pakpahan, 2020). Tidak semua strategi yang diterapkan menguntungkan anggota masyarakat. Sebagai contoh, penutupan wilayah skala terbatas maupun meluas telah menyebabkan penurunan pendapatan UMKM (Fathoni, 2020; Thaha, 2020), dan memberikan dampak terhadap masyarakat berpenghasilan rendah karena sangat berpengaruh bagi ruang gerak mereka untuk mencari nafkah (Nasruddin and Haq, 2020), penurunan perekonomian secara keseluruhan, dan pekerja yang dirumahkan (Herispon, 2020). Di sisi lain, kebijakan pengendalian wilayah yang ketat justru merugikan mereka yang secara ekonomi rapuh dan akan menyebabkan tingkat kepatuhan yang rendah (Maysoon et al., 2020). Kelompok ekonomi rapuh dan terdampak besar adalah kelompok usaha yang membutuhkan keramaian massa, 
kelompok pekerja harian lepas, pedagang kaki lima, para buruh yang terdampak PHK, petani, masyarakat miskin, dan sebagainya (Kurniawansyah et al., 2020). Selain itu, sektor produksi berbasis pertanian dan perikanan merupakan dua sektor yang terdampak besar. Sektor perikanan mengalami kerentanan berlapis akibat berbagai kebijakan penangan Covid-19 yang kurang memperhatikan kebutuhan nelayan, terutama dalam distribusi hasil tangkapan (Talib, Herawati, dan Limbengpiah, 2020).

Berbagai penelitian tersebut menunjukkan bahwa dampak ekonomi akibat pandemi Covid-19 mengisyaratkan munculnya permasalahan sosial-ekonomiyang berat dan kemiskinan, yakni ketidakmampuan untuk mencapai standar hidup minimum (Buheji et al., 2020). Dengan demikian, mengetahui bagaimana kelompok rentan beradaptasi dan menyusun strategi bertahan hidup merupakan hal penting untuk dilakukan, baik secara individual maupun kelompok untuk mencari solusi, baik masalah yang bersifat individual maupun sosial (Ross, Mitchell, and May, 2012). Dalam situasi ketidakpastian ini, ada bukti bahwa ketidakpastian ketahanan ekonomi keluarga membuat masyarakat kelas menengah ke bawah "terpaksa" mendobrak nalar rasionalitas negara dalam kebijakan penanganan wabah pandemi Covid-19 di Indonesia (Harirah, Zulfa dan Rizaldi, 2020). Bagi mereka yang kehilangan pendapatan dan menurunnya daya beli kaum miskin (Béné, 2020), banyak strategi koping yang dilakukan pada tatatan rumah tangga, antara lain likuidasi aset (misalnya ternak), realokasi tenaga kerja, perubahan pengeluaran dan konsumsi rumah tangga, penggunaan simpan pinjam formal dan informal,ketergantungan pada jaringan dukungan keluarga dan masyarakat (kekerabatan) serta organisasi eksternal (Paumgarten et al., 2020).

Penelitian tersebut menunjukkan strategi koping terhadap situasi krisis yang dilakukan oleh banyak rumah tangga kelas menengah ke bawah. Kemudian bagaimana pekerja-pekerja sektor informal, khususnya keluarga muda, berusaha keluar dari tekanan ekonomi ini? Sebuah penelitian menunjukkan bahwa lebih dari separuh keluarga muda merasa cukup tertekan secara objektif dan subjektif dalam hal ekonomi, sertaada hubungan antara tekanan ekonomi dan manajemen keuangan dalam keluarga (Raharjo, Puspitawati, and Pranaji, 2015). Penelitian lain menunjukkan posisi strategis jaringan sosial,baik secara informal maupun formal, dengan lingkungan sosialnya dan lingkungan kelembagaan. Pemanfaatan jaringan ini terlihat jelas dalam mengatasi masalah ekonomi dengan pinjam uang kepada orang terdekat (terutama pada saudara, tetangga, teman kerja), hutang di warung terdekat, bahkan ada yang pinjam uang ke rentenir (Gunawan dan Sugiyanto, 2011). Strategi-strategi koping yang selalu dilakukan keluarga adalah membeli pangan yang lebih murah, mengubah distribusi pangan, mengganti obat yang mahal dengan obat murah, memilih tempat berobat yang lebih murah, menangguhkan pengobatan, mengurangi pembelian pakaian, dan mengurangi pembelian perabot rumah tangga. Strategi koping pengurangan pengeluaran lebih mudah dilakukan keluarga dibandingkan dengan strategi penambahan pendapatan (Herawati, Tyas, and Trijayanti, 2017).

Untuk menjelaskan bagaimana keluarga muda menghadapi situasi sulit, artikel ini berfokus pada analisis menggunakan modal sosial yang elemennya terdiri atas kepercayaan, norma, dan jaringan. Ketiga elemen tersebutmerupakan kesatuan dan memiliki hubungan yang erat serta saling mendukung, sehingga membentuk satu jaringan (Widiara, et al., 2009: 300). Dalam konteks Covid-19, modal sosial (social capital) menarik untuk dicermati, terutama mencakup kepercayaan sosial, afiliasi kelompok, keterlibatan sipil, kepercayaan pada lembaga negara, ketidaksetaraan 
Optimalisasi Modal Sosial Keluarga Muda dalam Membangun Ketahanan Ekonomi di Era Covid-19: Studi Kasus di Perdesaan Jawa

pendapatan, dan tingkat kematian (Lindström, 2020). Secara konseptual, modal sosial adalah konstruksi teoretis luas yang tentang sumberdaya sosial dari "hubungan yang dilembagakan dari saling kenal dan pengakuan". Dimensi inti modal sosial dalam hal ini adalah ikatan kuat dan erat antara anggota keluarga dan teman dekat, longgarnya hubungan kelompok, dan yang penting adalah bahwa dimensi modal sosial dalam konteks pandemic ini belum banyak dikaji (Elgar, Stefaniak and Wohl, 2020).Studi hubungan antara modal sosial dan Covid-19 menunjukkan adanya beragam respon terkait pandemic ini, termasuk bagaimana modal sosial bekerja(Wu, 2020). Ada dua jenis jaringan sosial, yaitujaringan tertutup dari keluarga dan teman danjaringan terbuka yang menjembatani berbagai komunitas (Beugelsdijk and Smulders, 2003). Penulis ini memandangnya sebagai seperangkat "asosiasi horizontal" antara orang-orang, yaitu modal sosial yang terdiri atas jaringan sosial ("jaringan keterlibatan sipil") dan norma-norma terkait yang berpengaruh pada produktivitas komunitas. Dua praduga empiris yang mendasari konsep ini adalah jaringan dan norma terkait secara empiris dan hal ini memiliki konsekuensi ekonomi yang penting. Ciri utama modal sosial dalam definisi ini adalah memfasilitasi koordinasi dan kerja sama untuk kepentingan bersama para anggota asosiasi (Grootaert, 1998). Modal sosial menggambarkan norma penghormatan dan jaringan hubungan saling percaya antara orang-orang yang berinteraksi melintasi gradien kekuasaan atau otoritas yang eksplisit, formal atau menjadi lembagadalam masyarakat (Claridge, 2018). Melalui perspektif tersebut, penelitian ini akan melihat bagaimana keluarga muda mengoptimalkan modal sosial dalam menghadapi dampak Covid-19 yang menyebabkan kondisi perekonomian mereka rentan.

\section{Metode penelitian}

Penelitian ini dilakukan di suatu dusun yang secara administratif termasuk dalam Kabupaten Sleman, Daerah Istimewa Yogyakarta. Secara fisiologis, dusun adalah pemukiman yang terbentuk secara alami yang dicirikan dengan terpisahnya lingkungan ini dari dusun lain oleh ladang dan sungai (Bebbington et al., 2006). Penelitian dilakukan pada periode Mei hingga Agustus 2020. Secara khusus penelitian ini berfokus pada keluarga yang dikategorikan sebagai keluarga muda dengan kriteria utama adalah keluarga dengan anak tertua berumur kurang atau sama dengan 10 tahun atau usia perkawinannya 0-10 tahun (Anggaunitakiranantika, 2013). Secara konseptual, konsep keluarga muda dalam penelitian ini berbeda dari konsep yang menempatkan keluarga muda sebagai keluarga yang memiliki suami dengan usia maksimum 30 tahun dan memiliki minimal satu anak dengan usia maksimal 6 tahun (Raharjo, Puspitawati and Pranaji, 2015). Ada alasan kuat mengapa penelitian ini berfokus pada keluarga muda. Sejauh ini, kajian yang menempatkan keluarga muda sebagai subjek penelitian terkait situasi kerentanan ekonomi akibat pandemic Covid-19 belum ditemukan. Sementara itu, kajian tentang rumah tangga muda sangat penting karena secara sosial dan ekonomi, rumah tangga muda seperti ini pada umumnya belum memiliki kekuatan ekonomi yang baik atau ekonomi belum mapan (Patty, Pattiselanno and Kakisina, 2019).

Kasus dalam penelitian ini adalah tujuh keluarga dengan latar belakang yang berbeda, yakni keluarga muda yang memiliki latar belakang pekerjaan serabutan (informan melakukan satu atau lebih dari beberapa jenis pekerjaan, seperti sebagai penjaga toko, buruh bangunan, buruh tani, rentenir kecil, pengrajin anyaman bambu, pedagang makanan keliling, dan asisten rumah tangga). Dari tujuh keluarga kasus, 
satu keluarga terdapat istri yang tidak bekerja, sedangkan enam lainnya terdapat suami istri bekerja. Para informan dalam penelitian ini adalah kepala keluarga dan istri dari keluarga yang sangat berisiko kehilangan pekerjaan secara mendadak yang berarti mereka berisiko kehilangan pendapatan. Dalam penelitian ini, data utama dikumpulkan melalui pengamatan dan serangkaian wawancara untuk mendapatkan pemahaman mendalam dan membangun sebuah tesis baru tentang bagaimana keluarga muda pekerja sektor informal yang hidup dalam lingkungan masyarakat perdesaan mengalami dan merespons kesulitan hidup akibat adanya pandemi Covid-19.

\section{Hasil Penelitian}

Dalam menghadapi situasi sulit akibat adanya pandemi, ada berbagai respons yang dilakukan para keluarga muda. Ada tiga hal utama yang mereka lakukan, yaitu membangun kepercayaan, menerapkan norma baru dalam kehidupan, dan memelihara sekaligus mengoptimalkan jaringan sosial. Sebagaimana pengertian secara konseptual, kepercayaan dipandang sebagai proses untuk mengandalkan sesuatu yang memiliki target pasti, sementara norma sangat erat kaitannya dengan kepercayaan dan jaringan, sehingga hubungan keduanya tidak bisa dipisahkan. Norma muncul dari pertukaran yang saling menguntungkan. Karakter norma bersifat timbal balik dan berkaitan dengan banyak interaksi atau nilai sosial yang disepakati bersama dan saling menguntungkan bagi masyarakat. Unsur terakhir dalam modal sosial adalah jaringan yang dapat diartikan sebagai ikatan simpul antara manusia yang terhubung dengan interaksi sosial. Merujuk pada upaya operasionalisasi kerangka konseptual, berikut beberapa poin penting dalam temuan penelitian ini.

\section{Kepercayaan}

Bagi ketujuh keluarga yang menjadi informan studi kasus penelitian ini, membangun dan mendayagunakan kepercayaan pihak lain merupakan hal yang utama dan sesuatu yang selalu ditingkatkan. Sebagaimana masyarakat Indonesia pada umumnya, mereka juga merasakan adanya respons beragam atas kondisi pandemi, termasuk berbagai kebijakan reaktif pada awal munculnya Covid-19, yaitu penutupan wilayah di tingkat desa dan dusun serta kegiatan belajar tatap muka di sekolahsekolah di Yogyakarta yang belum aktif dilakukan. Bagi para informan, respons atas situasi pada awal pandemi ini telah mengagetkan dan menjadi pukulan telak bagi perekonomian rumah tangga. Sebagian besar informan terkesima dalam beberapa saat dan kaget menghadapi kenyataan pahit akibat munculnya permasalahan ekonomi yang muncul secara tiba-tiba. Mereka yang biasanya berdagang makanan di sekolah, tiba-tiba harus berhenti. Perajin, buruh petik padi, dan pekerja sektor lain mengalami hal yang sama. Berbagai kesulitan ekonomi dialami para pekerja sektor informal. Beragam respons dilakukan oleh pekerja informal untuk mengatasi kesulitan ekonomi akibat lockdown lokal dan berhentinya kegiatan secara normal.

"Satubulanpertamapandemimerupakan saat yang paling berat. Sebagai buruh petik padi, saat itu saya tahu bahwa padi produksi petani tidak laku. Tidak ada pembeli karena semua mandeg. Juragan tidak lagi menebas padi di sawah. Saya diuntungkan karena pada saat Juragan tidak mampu memberikan pekerjaan, tetangga sedang panen sehingga saya memburuh disana. Masalah muncul ketika ternyata bawon tidak bisa dijual. Saya punya gabah, tetapi tidak bisa dijual. Apabila ada pedagang yang beli, pembayarannya 
Optimalisasi Modal Sosial Keluarga Muda dalam Membangun Ketahanan Ekonomi di Era Covid-19: Studi Kasus di Perdesaan Jawa

minta tempo cukup lama. Gabah menumpuk tetapi tidak bisa diuangkan. Saya akhirnya cari sumber pendapatan lain yakni cari siput sawah di malam hari. Saya setor ke penjual angkringan karena usaha angkringan masih ada yang buka. Penjual mau menerima pasokan dari saya karena saya sudah kenal lama dan dia tahu kesulitan yang saya alami. Lumayan, satu kilogram siput bisa laku dua ribu rupiah. Semalam, apabila sedang beruntung, bisa mendapatkanlima puluh kilogram siput. Tapi saat ini saya tidak lagi cari. Kondisi sudah mulai normal. Beras sudah bisa dijual. Saat ini, yang penting semua masalah sudah terkendali, saya tidak lagi cari siput karena perekonomian sudah mulai normal. Saya perlu hemat tenaga untuk siap-siap seandainya situasi sulit kembali muncul. Kita tidak tahu ini..." (Heri A, 35 tahun, Buruh Petik Padi).

Berbekal kepercayaan dari teman, akhirnya Agus (umur 35 tahun, seorang kepala rumah tangga dengan dua anak usia 7 dan 1 tahun) bisa keluar dari masalahnya, yaitu tidak memiliki uang tunai untuk memenuhi kebutuhan sehari-hari. Mencari sumber penghidupan baru secara srabutan juga dilakukan oleh Dwi $\left(27^{\text {th }}\right)$. la yang biasa berjualan cireng di sekolah akhirnya berganti pekerjaan menjadi buruh bangunan. Kepala keluarga dengan satu anak usia 3 tahun ini merupakan korban PHK, atau tepatnya mengundurkan diri karena tempat kerjanya mengalami penurunan omset. Sebelum adanya Covid-19, ia bekerja di tempat tetangganya yang tinggaldi dusun yang sama sebagai pemasar produk onderdil motor. la tidak mendapatkan gaji bulanan, tetapi mendapatkan bonus. la akan menerima pendapatan sebesar $15 \%$ dari pendapatan selama satu minggu setelah dipotong biaya operasional berupa bensin, makan siang, dan penginapan.
"Saya terpaksa menganggur dan kerja serabutan. Setelah tidak bekerja sebagai tenaga pemasaran, saya berjualan Cireng di sekolah-sekolah. Pendapatan lumayan baik, tetapi menjadi kacau ketika saat ini sekolah tutup. Atas bantuan teman, saya saat ini bisa masuk ke proyek bangunan. Akhirnya istri harus bantu-bantu dengan berjualan apa saja. Makanan kecil yang dikemas ulang menjadi pilihan. Ternyata itu juga tidak banyak membantu. Sampai akhirnya, tetangga desa memberi alat setrum ikan. Jadilah saya kembali ke profesi lama, mencari ikan dengan strom. Saat ini pendapatan agak lumayan. Bila beruntung, bisa memperoleh uang seratus ribu sekali berangkat mencari ikan. Terlebih bila mendapatkan ikan kutuk, harga jual cukup tinggi, yakni enam puluh ribu rupiah per kilogram. Ikan saya jual ke tetangga karena sudah langganan. Berapapun hasil tangkapan, akan mereka beli." (Agus, 30 ${ }^{\text {th }}$, pekerja srabutan).

Dalam menghadapi situasi ekonomi yang serba sulit, hampir semua keluarga muda memiliki usaha baru yang dijalankan oleh istri, yaitu berdagang makanan kecil yang dijual secara online. Cara ini banyak menjadi pilihan perempuan muda di desa ini. Mereka memanfaatkan jaringan pertemanan dan jaringan keluarga. Seorang perempuan muda, dengan satu anak usia 1,5tahun yang ter-PHK dari sebuah bioskop cukup ternama di Kota Yogyakarta akhirnya memilih kegiatan ini. Dengan menggunakan jaringan pertemanan ibu mertuanya yang seorang guru, ia menawarkan produk makanan kecil dengan menjadi reseller. Perempuanperempuan perkasa muncul disituasi krisis. Hal ini yang tampak pada situasi pandemi ini. Mereka berusaha membantu dan bahkan mengambil alih peran suami dalam menopang kehidupan perekonomian keluarga. Kondisi ini terjadi pada keluarga 
Gareng (58 tahun). Laki-laki yang telat menikah ini saat ini memiliki anak usia 6 tahun. Bekerja sebagai buruh bangunan, ia menuturkan, "Saat ini saya pusing betul mas. Semua proyek berhenti. Ini sudah tiga bulan tidak ada pekerjaan, lontang-lantung tetapi harus makan terus."Dari wawancara dengan istrinya, Anik (35 tahun),akhirnya penelitian ini memperoleh gambaran betapa istri menjadi tumpuan:

"Beruntung mas, saya pernah ikut pelatihan membuat anyaman bambu dari Dinas Perindustrian di Bulan Pebruari 2020. Belum lagi ada pendampingan pemasaran, Covid-19 diumumkan masuk di Indonesia. Akhirnya dari 20 orang yang ikut pelatihan, hanya empat orang yang memutuskan untuk melanjutkan membuat produk. Itupun tidak laku. Beragam model anyaman kita buat sampai akhirnya baru di Bulan Juni mulai ada permintaan. Harga anyaman beragam. Ada yang seribu lima ratus rupiah dan termahal dua ribu lima ratus rupiah per buah. Pemasaran dilakukan oleh instruktur pelatihan, walaupun kita juga dibebaskan kalau mau menjual ke siapa saja. Di saat sepi, saya membantu pengrajin lain, yang kebetulan masih saudara...merapikan anyaman dengan upah dua ribu rupiah setiap satu Kodi atau 40 biji. (Anik, 35 tahun, istri buruh bangunan).

Anik dan empat pengrajin lainnya saat ini aktif memproduksi aneka anyaman dari bambu untuk memenuhi kebutuhan restoran, toko buah, dan toko asesoris. Meski demikian, penentuan jenis produk anyaman ditentukan oleh pihak pedagang perantara.

Selain mendayagunakan kepercayaan orang-orang sekitar dalam mengembangkan usaha, beberapa keluarga muda berusaha untuk membangun keyakinan orang lain, khususnya terkait upaya mendapatkan bantuan. Hal ini disebabkan adanya perasaan ketidakadilan proses penyaluran bantuan keluarga terdampak Covid-19 yang diterima keluarga muda, terutama perlakuan dari aparat dusun. Dalam konteks keluarga atau rumah tangga penerima bantuan Covid-19, baik yang berasal dari pemerintah maupun pihak swasta, para keluarga ini berusaha membangun narasinya sendiri ketika mereka secara kebetulan tidak masuk dalam skema penerima bantuan. Ada pola yang jelas bagaimana para keluarga yang terdampak ini berusaha untuk meyakinkan pihak yang dipandang mampu meloloskan dia untuk menerima bantuan.

"Saya protes keras ketika tahu bahwa keluarga saya tidak termasuk penerima bantuan sosial, sementara saya melihat banyak warga yang lebih mampu dari saya justru menerima, Pak RT, Pak RW, dan masih banyak lagi orang menerima. Saya hanya bekerja sebagai pembantu, tukang cuci baju, dan suami buruh bangunan. Anak saya dua masih kecilkecil, Iha kok saya nggak dapat bantuan Covid-19. Saya labrak dan protes ke Pak Dukuh dan sampaikan keberatan. Akhirnya di bulan berikutnya saya mendapatkan bantuan."(Mur, 40 ${ }^{\text {th, }}$, istri buruh bangunan dan petani penggarap).

\section{Pengelolaan Jaringan Sosial}

Jaringan sosial memiliki peran penting dalam kehidupan keluarga yang menjadi informan penelitian ini. Bambang, seorang Iulusan PTS di Yogyakarta, menyampaikan bahwa menghadapi pandemiCovid-19 merupakan halyang berat. Jauh sebelum Covid-19, ia sudah menganggur cukup lama karena proyek pembangunan TOL yang ia ikuti sudah selesai. la selalu menggantungkan diri pada panggilan kerja dari temannya yang bekerja di sebuah perusahaan BUMN pembangunan insfrastruktur. Dalam menghadapi Covid-19, 
ia merasakan pahitnya sebagai kelompok yang terlupakan. Bantuan dari pemerintah tidak ia dapatkan karena ia bukan termasuk orang tidak mampu. Sedangkan fakta yang ditemui adalah ia sudah lama menganggur, hidup seadanya. Oleh sebab itu, ia berpikir harus gigih dan ulet mencari bantuan. Pada akhirnya, ia bisa memperoleh bantuan melalui jaringan partai dan saudara yang kenal dengan pihak pengelola bantuan.

"Saya mencari bantuan melalui partai wong cilik. Akhirnya setelah menghubungi ibu yang menjadi anggota DPR, mendapatkan jatah dua ratus ribu rupiah setiap bulan untuk tiga bulan. Uang ini hasil dari program bantuan Covid-19 yang besarnya enam ratus ribu rupiahperkeluarga, tetapi karena saya tidak terdaftar maka jatah itu dibagi untuk tiga keluarga. Itu saya tidak tahu dua keluarga yang lain siapa. Saya akhinya juga berusaha melalui sekolah. Anak mendapatkan dana PIP masing-masing empat ratus lima puluh ribu rupiah atas bantuan partai Restorasi untuk satu tahun. Saya juga sedangmengurus untuk anak ketiga agar mendapatkan bantuan juga. Ada juga bantuan sembako dari sekolah, yaitu pernah sekali mendapatkanlima kilogramberas, satu literminyak goreng, dan satu kilogram gula pasir. Hidup berat sekali saat ini, saya sudah lama menganggur dan tidak punya penghasilan sama sekali. Untuk masak, perlu satu setengah kilogram beras dan telurper hari. Anak terkecil senang sekali makan telur. Sehari bisa dua atau tiga butir. Kalau dua anak yang lain tidak suka, cukup makan dengan sayur. Ini, jam sepuluh sudah makan untuk ketiga kalinya" (Bambang, 40 tahun, pekerja sektor informal).

Kisah lainnya berasal dari Karyo (50 tahun), seorang buruh bangunan dan penggarap sawah dengan pendidikan lulusan SD. la menyampaikan bagaimana ia melakukan upaya untuk tetap bekerja. Bagi Karyo, ada Covid-19 atau tidak, ia tetap dan harus bisa menjalankan pekerjaanya.

"Ketika Covid-19 diumumkan pada bulan Maret, banyak desa melakukan penutupan wilayah. Banyak kegiatan pembangunan berhenti. Tetapi saya tetap bekerja. Saya punya banyak teman dan kenal baik dengan bosbos pembangunan. Mereka tetap mengerjakan proyek walaupun ukurannya kecil-kecil, seperti renovasi rumah pribadi. Saya tetap diprioritaskan bekerja. Walaupun keluar masuk kampung disemprot desinfektan, saya tetap jalani. Saya juga selalu pakai maskerdan mengikuti aturan kesehatan. Mengapa Bos selalu mencarikan pekerjaan ke saya? Karena saya selalu pamitan setiap ada halangan. Saya juga selalu jujur. Kalau banyak pekerja main di semen dan campuran, saya tidak pernah mau diajak. Bangunan ini untuk sekolah, untuk anak cucu. Kalau cepat rusak atau roboh, siapa yang rugi? Jangan-jangan nanti anakmu ikut jadi korban. Itu yang saya selalu sampaikan ke buruh-buruh bangunan teman-teman saya. Bos akhirnya tahu dan sepakat"(Karyo, 50 tahun. Petani penggarap dan buruh bangunan).

Disisi lain, melakukan diversifikasi sumber pendapatan merupakan strategi yang banyak dilakukan oleh para keluarga muda. Sebagaimana dilakukan Agung, Karyo juga melakukan banyak kegiatan.

"Walau saya bekerja keras selama pandemi Covid-19, saya tetap mengolah lahan garapan. Saya mengolah sawah dari dua pemilik, masing-masing seribu lima ratus dan dua ribu lima ratus meter persegi. Sawah yang pertama 
bisa menghasilkan satu ton gabah dan saya mendapatkan lima ratus kilogram. Sawah kedua, karena milik orang kota, panenan selalu dijual. Sekali panen bisa mendapatkan uang dua juta sampai duajuta dua ratus lima puluh ribu rupiah. Saya harus melakukan itu agar ada sumber yang lain selain upah sebagai buruh. Apabila musim pengolahan sawah tiba, saya selalu minta ijin untuk tidak bekerja. Bos biasanya maklum dan tahu kalau saya tidak bohong. Dia pasti akan bilang, nggak apa-apa kalau sudah selesai di sawah, segera gabung kesini lagi. Kalau kesini sudah selesai, nanti kamu saya hubungi untuk kerja di tempat lain. Karena saya dekat dengan Bos, saya bisa memilih lokasi proyek yang dekat dan punya jam kerja mulai pukul 08.00. Saya nggak pernah mau lembur, baik lembur dengan cara menambah jam kerja denganmulai bekerja lebih awal atau pulang lebih lambat. Saya setiap pagi harus ke sawah. Pukul setengah lima pagi ketika azan subuh terdengar, saya akan langsung ke sawah sampai pukul setengah tujuh pagi. Lalu pulang dan istirahat sebentar, baru kemudian berangkat ke proyek." (Karyo, 50 tahun, petani penggarap dan buruh bangunan).

\section{Norma}

Norma selalu dipahami dalam pengertian yang positif. Penelitian ini menemukan bahwa dalam situasi krisis dan keadaan serba tidak jelas ini, masyarakat yang hidup pada situasi kerentanan akut ternyata menciptakan norma baru untuk mendukung sikap subsistenya. Apa yang dilakukan Bambang, dengan mencari sumbangan dari berbagai sumber, merupakan contoh nyata bagaimana dalam situasi kerentanan akut, seseorang bisa melakukan apa saja, termasuk mencoba mengakumulasi bantuan dari banyak sumber untuk kepentingan keluarga sendiri. Demikian juga perilaku protes terhadap aparat oleh Mur. Warga yang mengetahui pada saat Mur protes mengungkapkan. "Murprotes dengan sangat kasar, banyak hewan kebun binatang keluar dari mulutnya. Bu Dukuh sampai shock dan jatuh sakit". Observasi menunjukkan bahwa beberapa keluarga muda menganggap hal itu wajar karena apabila tidak melakukan hal tersebut, maka bantuan tidak akan merata.

Kisah Wawan (35 tahun) merupakan contoh lain terkait penerapan norma dalam berusaha. Seorang lulusan SMK ini memiliki usaha mandiri berupa peminjaman uang. Tanpa badan hukum, ia meminjamkan uang dengan model pengembalian 10 minggu (10 kali) untuk setiap peminjaman. Apabila seseorang meminjam Rp 500.000,- maka ia akan menerima $\mathrm{Rp} 450.000,-$. Uang pinjaman ia potong pada awal peminjaman, yaitu sebesar Rp 50.000,- sebagai biaya administrasi. Peminjam diwajibkan mengembalikan Rp 60.000,- sebanyak 10 kali dan diangsur per minggu. Pada saat ini, uang yang beredar di nasabah sekitar Rp 20.000.000,-. Dengan omset sebesar itu, ia mendapatkan pendapatan berupa angsuran pokok dan bunga sebesar Rp 2.400.000,per minggu atau pendapatan bersih Rp 400.000,- per minggu dari bunga pinjaman. Selain usaha pribadi, ia juga bergabung dengan teman-temannya dalam usaha meminjamkan uang.

"Dalam satu minggu, dua hari saya pakai untuk menjalankan usaha sendiri, yakni Senin dan Selasa. Kemudian Rabu sampai Jumat, saya gunakan untuk bekerja dengan teman-teman dengan kelompok. Saya termasuk yang nggak terlalu berhasil dalam usaha. Temanteman saya sudah banyak yang mampu membeli kendaraan baru, beli tanah, dan membangun rumah. Baru mau bangkit dan menghindari kebiasaan berjudi melalui kegiatan memancing, tiba-tiba ada Covid-19. Semua repot 
dan terpengaruh. Banyak kampung dan perumahan tutup. Banyak juga nasabah yang sulit ditagih. Mereka menunjukkan surat keterangan terdampak Covid-19. Akhirnya mereka hanya bayar bunga. Uang akhirnya mandeg."(Iwan, 30 tahun, pekerja sektor informal, usaha simpan pinjam uang mandiri).

\section{Pembahasan}

Banyak studi mengungkapkan bahwa lockdown secara ekonomi telah berdampak cukup besar bagi kehidupan perekonomian di berbagai negara, seperti Italia (Navaretti et al., 2020) serta memperburuk berbagai ketidaksetaraan yang sudah ada sebelumnya dan berdampak panjang (Blundell et al., 2020). Dari studi kasus ini, kondisi yang sama juga terjadi di Indonesia. Meskipun lockdown hanya bersifat sporadis dan merupakan strategi pembatasan sosial berskala menengah, ternyata dampak perekonomian bagi para keluarga yang bekerja di sektor informal cukup besar. Kondisi ini mengonfirmasi bahwa secara ekonomi, adanya goncangan sesaat yang menyebabkan mereka berhenti untuk sementara dalam mencari nafkah merupakan faktor penting yang akan menggoyahkan kehidupan perekonomian keluarga.

Dalam studi ini, para keluarga muda tidak mengalami dampak berkepanjangan secara ekonomi karena kemampuan mereka mengelola dan mengoptimalkan kepercayaan, norma, dan jaringan sosial, sehingga menjadi kekuatan bagi keluarga muda di perdesaan dalam menghadapi dampak buruk akibat pandemi Covid-19. Dengan menerapkan ketiga hal tersebut dalam kehidupannya, para keluarga muda mampu tetap bertahan dan memenuhi kebutuhan minimum dari hasil kerja keras dan tidak semata menggantungkan diri pada bantuan pihak lain. Penelitian ini menunjukkan bahwa para keluarga muda, dengan keterbatasan sumberdaya, memiliki daya lentur dan daya adaptasi yang tinggi. Berbeda dari berbagai penelitian yang menunjukkan dampak buruk pandemi bagi relasi-relasi dalam keluarga berupa munculnya kekerasan rumah tangga, penelitian ini menemukan adanya kekompakan dan kerja sama antara suami dan istri. Hasil ini tentu saja menarik dan merupakan sinyal bagus bahwa dalam situasi dampak ekonomi yang sangat berat akibat pandemi, para keluarga muda di daerah perdesaan mampu mengoptimalkan modal sosial untuk beradaptasi. Dengan demikian, mereka memiliki kemampuan beradapatasi yang bagus dan mencari solusi untuk keluar dari tekanan dalam keluarga. Suatu kemampuan yang muncul akibat adanya diversifikasi pendapatan pada rumah tangga tersebut (Ellis, 1998).

Sebagaimana temuan penelitian lain bahwa konsekuensi negatif lain dari pandemi Covid-19 adalah masalah jam kerja yang lebih panjang, dampak lain dapat dilihat dari adanya perubahan jam kerja yang tidak hanya dirasakan perempuan (Collins et al., 2020) tetapi juga laki-laki. Hal ini merupakan konsekuensi logis bagi para pasangan muda ini, karenabagi mereka pandemi hanya dapat dihadapi dengan kerja keras dan kerja cerdas, yaitu mencari peluang agar tetap bisa memenuhi kebutuhan rumah tangganya. Upaya ini dapat dilakukan apabila sumberdaya keluarga, yakni suami dan istri bekerja sama dalam mencari sumber-sumber pendapatan alternatif.

Pandemi Covid-19 telah menjadi bagian dari berbagai penyebab kelompok rentan mencari berbagai peluang untuk mendapatkan penghasilan (Hilson and Banchirigah, 2009). Strategi koping saat kondisi krisis yang sering ditemukan pada keluarga-keluarga terdampak krisis, seperti penurunan konsumsi beras tidak ditemukan dalam keluarga ini. Hal ini berbeda daritemuan yang menunjukkan pengurangan makanan banyak menjadi pilihan strategi koping (Handayani, Sri 
Wening dan Burkley, 2009). Mekanisme koping mereka adalah menumbuhkan ikatan yang kuat dengan komunitas mereka (Constant, 2020) dan relasi internal keluarga. Dari keluarga-keluarga yang dijadikan studi kasus, tidak ditemukan adanya strategi meminjam dari pihak untuk mengatasi saatsaat sulit sebagaimana ditemukan dalam berbagai studi di komunitas rentan lain, seperti nelayan (Ferse et al., 2012). Studi ini menemukan adanya berbagai upaya melangsungkan kehidupan tanpa hutang dan para keluarga muda mengorbankan nilai gizi dalam penyediaan makanan bagi anakanaknya tanpa mengurangi kuantitas, seperti penuturan informan, "Yang penting anakanak kenyang". Nilai yang dianut adalah "Yang penting bisa jalan roda ekonomi, tidak perlu memikirkan lauk seperti itu" menjadi jawaban klasik ketika membicarkan tentang kualitas makanan yang dikonsumsi seharihari.

\section{Kesimpulan}

Penelitian ini mengonfirmasi beberapa penelitian sebelumnya bahwa pilihan kebijakan berupa penutupan wilayah dan penghentian kegiatan bisnis dan sekolah dalam menghadapi pandemi memiliki dampak besar bagi rumah tangga pekerja sektor informal. Studi ini menunjukkan bahwa rumah tangga pekerja sektor informal di perdesaan memiliki daya lentur yang baik dalam menghadapi dampak ekonomi dari pandemi, sehingga mereka bisa segera menyesuaikan diri dengan situasi dan mencari strategi-strategi baru untuk memenuhi kebutuhan pangan keluarga. Dengan demikian, meskipun pandemi Covid-19 telah menyebabkan berbagai dampak nonkesehatan akut bagi berbagai lapisan masyarakat, keluarga muda di perdesaan Jawa lebih bisa memiliki peluang keluar dari tekanan ekonomi karena masih ada peluang-peluang kerja bagi keluargakeluarga muda di perdesaan Jawa.
Keluarga muda, yaitu mereka yang menikah kurang dari 10 tahun dan/atau memiliki anak tertua berusia kurang dari 10 tahun, mengoptimalkan dan membangun modal sosial berupa kepercayaan yang mereka peroleh dari pihak lain, mengembangkan norma kehidupan yang dirasa cocok bagi penguatan eksistensi di lingkungannya dan menggunakan jaringan sosial berupa jaringan kekerabatan dan pertemanan. Tiga faktor penting tersebut menjadi kekuatan rumah tangga muda untuk keluar dari tekanan ekonomi pada masa pandemi ini. Kondisi tersebut menyebabkan mereka menjadi kelompok paling rentan sekaligus mampu menghadapi situasi darurat secara ekonomi.

Bagi keluarga muda, situasi pandemi telah mengajarkan mereka tentang makna membangun kepercayaan, meningkatkan kapasitas diri, dan keluarga dalam menyusun strategi untuk menghadapi kerentanan ekonomi, termasuk menyusun strategi dalam mengelola kondisi kesehatan dan jam kerja, melakukan berbagai kombinasi kegiatan ekonomi produktif untuk melangsungkan kehidupan. Keluarga muda yang menjadi subjek penelitian saat ini mulai memahami makna berumah tangga sebagai kesatuan ekonomi dan melakukan pengelolaan pendapatan yang minim secara cermat, sehingga mampu bertahan dan memenuhi kebutuhan minimum rumah tangga. Penelitian ini menemukan bahwa dalam upaya memenuhi kebutuhan minimum makan, keluarga muda melupakan aspek kualitas gizi. Studi lanjutan perlu dilakukan, khususnya terkait dampak strategi ini bagi kondisi kesehatan anak, yang dalam beberapa studi lain telah teridentifikasi sebagai kelompok paling rentan terdampak pandemi Covid-19 (Pérez-Escamilla, Cunningham and Moran, 2020). Sebagaimana penelitian tentang Covid-19 lainnya, penelitian lebih lanjut masih diperlukan, yaitu seberapa besar kemampuan keluarga muda menghadapi 
situasi krisis jika dampak pandemi Covid-19 berlangsung dalam jangka waktu lama, khususnya dalam hal perilaku dan untuk melakukan identifikasi strategi apa yang diperlukan untuk mendukung kehidupan rumah tangga dalam konteks pandemi (Carroll et al., 2020). Hal positif dari perilaku keluarga muda ini adalah bahwa dalam situasi krisis dan tekanan ekonomi yang berat, kekerasan dalam rumah tangga akibat kondisi rentan ini tidak ditemukan. Dengan demikian, hal ini berbeda dari berbagai penelitian lain yang menemukan fenomena kekerasan dalam rumah tangga akibat pandemi (Usher et al., 2020; Campbell, 2020; Humphreys, Myint and Zeanah, 2020).

\section{Daftar Pustaka}

Anggaunitakiranantika. 2013. 'Pola Pengambilan Keputusan Mengenai Partisipasi Dalam Program Keluarga Berencana Pada Keluarga di Kota Malang', Sejarah dan Budaya, 1, pp. 51-61.

Bebbington, A. et al. 2006. 'Local Capacity, Village Governance, and the Political Economy of Rural Development in Indonesia', World Development, 34(11), pp. 1958-1976. doi: 10.1016/j. worlddev.2005.11.025.

Béné, C. 2020. 'Resilience of local food systems and links to food security - A review of some important concepts in the context of COVID-19 and other shocks', Food Security. Food Security, 12(4), pp. 805-822. doi: 10.1007/s12571-02001076-1.

Beugelsdijk, S. and Smulders, S. 2003. Bridging and Bonding Social Capital: Which type is good for economic growth?, ERSA. Available at: http:// www-sre.wu-wien.ac.at/ersa/ersaconfs/ ersa03/cdrom/papers/517.pdf.

Blundell, R. et al. 2020. 'COVID-19 and Inequalities*', Fiscal Studies, 41(2), pp. 291-319. doi: 10.1111/1475-5890.12232.
Buheji, M. et al. 2020. 'The Extent of COVID-19 Pandemic Socio-Economic Impact on Global Poverty. A Global Integrative Multidisciplinary Review', American Journal of Economics, 10(4), pp. 213-224. doi: 10.5923/j. economics.20201004.02.

Campbell, A. M. 2020. 'An increasing risk of family violence during the Covid-19 pandemic: Strengthening community collaborations to save lives', Forensic Science International: Reports. Elsevier B.V., 2(April), p. 100089. doi: 10.1016/j. fsir.2020.100089.

Carroll, N. et al. 2020. 'The impact of covid-19 on health behavior, stress, financial and food security among middle to high income canadian families with young children', Nutrients, 12(8), pp. 1-14. doi: 10.3390/nu12082352.

Claridge, T. 2018. 'Functions of social capital - bonding, bridging, linking', Social Capital Research, (January), pp. 1-7.

Collins, C. et al. 2020. 'COVID-19 and the Gender Gap in Work Hours', Gender, Work and Organization, (June), pp. 1-12. doi: 10.1111/gwao.12506.

Constant, A. F. 2020. Time-Space Dynamics ofReturnand CircularMigration: Theories and Evidence. GLO Discussion Paper, No. 446. Global Labor Organization (GLO), Essen.

Elgar, F. J., Stefaniak, A. and Wohl, M. J. A. 2020. 'The trouble with trust: Timeseries analysis of social capital, income inequality, and COVID-19 deaths in 84 countries', Social Science and Medicine. Elsevier Ltd, 263(September), p. 113365. doi: 10.1016/j.socscimed.2020.113365.

Ellis, F. 1998. 'Household strategies and rural livelihood diversification', Journal of Development Studies, 35(1), pp. 1-38. doi: $10.1080 / 00220389808422553$.

Fathoni, A. 2020. 'Dampak Covid-19 dan Kebijakan PSBB Pemerintah terhadap UMKM di Wiyung Surabaya', Dinar: Jurnal Prodi Ekonomi Syari'ah, 3(1), pp. 30-69. 
Ferse, S. C. A. et al. 2012. 'Livelihoods of Ornamental Coral Fishermen in South Sulawesi/Indonesia: Implications for Management', Coastal Management, 40(5), pp. 525-555. doi: 10.1080/08920753.2012.694801.

Grootaert, C. 1998. Social capital: The missing Link? Social Capital Initiative. Wokring Paper No. 3. The World Bank. 3. Washington, DC.

Gunawan, S. 2011. 'Pasca Pemutusan Hubungan Kerja', Jurnal Penelitian dan Pengembangan Kesejahteraan Sosial, 16(01), pp. 35-52.

Handayani, Sri Wening dan Burkley, C. 2009. About Social Assistance and Conditional Cash Transfers: Proceedings of the Regional Workshop. Asian Development Bank.

Harirah, Zulfa dan Rizaldi, A. 2020. 'Merespon Nalar Kebijakan Negara Dalam Menangani Pandemi Covid 19 Di Indonesia', Jurnal Ekonomi dan Kebijakan Publik Indonesia, 7(1), pp. 36-53. doi: 10.24815/ekapi.v7i1.17370.

Herawati, T., Tyas, F. P. S. and Trijayanti, L. 2017. 'Tekanan Ekonomi, Strategi Koping, dan Ketahanan Keluarga yang Menikah Usia MUda', Jurnal IImu Keluarga dan Konsumen, 10(3), pp.181191. doi: 10.24156/jikk.2017.10.3.181.

Herispon. 2020. 'Dampak ekonomi pembatasan sosial berskala besar terhadap masyarakat kota pekanbaru di provinsi riau', Riau Economic and Business Review, 11(2), pp. 164-173.

Hilson, G. and Banchirigah, S. M. 2009. 'Are alternative livelihood projects alleviating poverty in mining communities? Experiences from Ghana', Journal of Development Studies, 45(2), pp. 172196. doi: $10.1080 / 00220380802553057$.

Humphreys, K. L., Myint, M. T. and Zeanah, C. H. 2020. 'Increased risk for family violence during the COVID-19 pandemic', Pediatrics, 146(1). doi: 10.1542/peds.2020-0982.
Kurniawansyah, H. et al. 2020. 'Konsep Kebijakan Strategis Dalam Menangani Eksternalitas Ekonomi Dari Covid - 19 Pada Masyarakat Rentan Di Indonesia', Indonesian Journal of Social Sciences and Humanities, Vol. 1(2), pp. 130139. Available at: file:///C:/Users/User/ Downloads/fvm939e.pdf.

Lindström, M. 2020. 'A commentary on "The trouble with trust: Time-series analysis of social capital, income inequality, and COVID-19 deaths in 84 countries"', Social Science \& Medicine. Elsevier Ltd, (September), p. 113386. doi: 10.1016/j. socscimed.2020.113386.

Maysoon, D. et al. 2020. 'COVID-19 control in low-income settings and displaced populations: what can realistically be done?', London School of Hygiene and Tropical medecine, pp. 1-10. Available at: https://www.lshtm.ac.uk/newsevents/ news/2020/covid-19-control-lowincome-settings-and-displacedpopulations-what-can.

Nasruddin, R. and Haq, I. 2020. 'Pembatasan Sosial Berskala Besar (PSBB) dan Masyarakat Berpenghasilan Rendah', SALAM: Jurnal Sosial dan Budaya Syar-i, 7(7). doi: 10.15408/sjsbs.v7i7.15569.

Navaretti, G. B. et al. 2020. 'In and out lockdowns: Identifying the centrality of economic activities', in Covid Economics: Vetted and Real-time Papers, pp. 189204.

Nicola, M. et al. 2020. 'The socio-economic implications of the coronavirus pandemic (COVID-19): A review', International Journal of Surgery. Elsevier, 78(March), pp. 185-193. doi: 10.1016/j.jjsu.2020.04.018.

Pakpahan, A. K. 2020. 'Covid-19 Dan Implikasi Bagi Usaha Mikro, Kecil, Dan Menengah', Jurnal IImiah Hubungan Internasional, 0(0), pp. 59-64. doi: 10.26593/jihi.v0i0.3870.59-64.

Patty, Y. S., Pattiselanno, A. E. and Kakisina, L. O. 2019. 'Resiliensi Nafkah Rumah 
Tangga Di Pulau Kecil (Studi Kasus Di Negeri Paperu Pulau Saparua Propinsi Maluku)', Agrilan: Jurnal Agribisnis Kepulauan, 7(3), p. 241. doi: 10.30598/ agrilan.v7i3.905.

Paumgarten, F. et al. 2020. 'Prepare for the unanticipated: Portfolios of coping strategies of rural households facing diverse shocks', Journal of Rural Studies. Elsevier Ltd, (March 2018). doi: 10.1016/j.jurstud.2020.05.013.

Pérez-Escamilla, R., Cunningham, K. and Moran, V. H. 2020. 'COVID-19 and maternal and child food and nutrition insecurity: a complex syndemic', Maternal and Child Nutrition, 16(3), pp. 8-11. doi: $10.1111 / \mathrm{mcn} .13036$.

Putri, R. K. et al. 2020. 'Efek Pandemi Covid-10: Dampak Lonjakan Angka PHK Terhadap Penurunan Perekonomian di Indonesia', Jurnal Bismak, 1(1), pp. 50-55.

Raharjo, I. T., Puspitawati, H. and Pranaji, D. K. 2015. 'Tekanan Ekonomi, Manajemen Keuangan, dan Kesejahteraan pada Keluarga Muda', Jurnal IImu Keluarga dan Konsumen, 8(1), pp. 38-48. doi: 10.24156/jikk.2015.8.1.38.

Ross, T., Mitchell, V. A. and May, A. J. 2012. 'Bottom-up grassroots innovation in transport: Motivations, barriers and enablers', Transportation Planning and Technology, 35(4), pp. 469-489. doi: 10.1080/03081060.2012.680820.

Setiati, S. and Azwar, M. K. 2020. 'COVID-19 and Indonesia', Acta Med Indones Indones J Intern Med, 52(1), pp. 84-89.
Talib, Naimah L, Herawati, Susan dan Limbengpiah, F. 2020. 'Kerentanan Kontekstual Pekerja Informal Ekonomi Kelautan: Studi Kasus Kebijakan Publik dalam Penanganan Covid-19 di Aceh dan Sulawesi Utara', in Pratiwi, A. M. (ed.) Ekonomi Informal di Indonesia: tinjauan Kritis Kebijakan Ketenagakerjaan. Jakarta, pp. 161-189.

Thaha, A. F. 2020. 'Dampak Covid-19 Terhadap UMKM di Indonesia', Jurnal Brand, 2(1), pp. 147-153. Available at: https://ejournals.umma.ac.id/index.php/ brand\%0Ae-ISSN.

Usher, K. et al. 2020. 'Family violence and COVID-19: Increased vulnerability and reduced options for support', International Journal of Mental Health Nursing, 29(4), pp. 549-552. doi: 10.1111/inm.12735.

Widiara, Aero, Rosyida Isma, Gandj Rajib, and Muswar, H. S. 2009. 'Peasant Empowerment Through Social Capital Reinforcement: Road to Sustainable Organic Agriculture Development (Case Study: Indonesian Peasant Union, Ciberum Situleuntik Village, Drabmaga Bogor, West Java)', Asian Journal of Food and Agro-Industry, Spesial Is, pp. 297-306.

Wu, C. 2020. 'Social capital and COVID-19: a multidimensional and multilevel approach', Chinese Sociological Review. Routledge, 0(0), pp. 1-28. doi: 10.1080/21620555.2020.1814139. 